\title{
An uncommon feeding habit: mutillid wasps (Hymenoptera, Mutillidae) visiting extrafloral nectaries in Malpighiaceae
}

\author{
D. R. Luz $^{a}$ * B. B. Rosa ${ }^{a}$, K. A. Williams ${ }^{b}$ and G. A. R. Melo ${ }^{a}$ \\ aLaboratório de Biologia Comparada de Hymenoptera, Departamento de Zoologia, Universidade Federal do Paraná - \\ UFPR, Av. Cel. Francisco Heráclito dos Santos, s/n, Jardim das Américas, CP 19020, CEP 81530-980, Curitiba, PR, Brazil \\ ${ }^{b}$ Division of Plant Industry, Florida Department of Agriculture and Consumer Services, \\ Florida State Collection of Arthropods, 1911 SW 34th St., Gainesville, FL 32608, USA \\ *e-mail:drdaluz@gmail.com
}

Received: January 28, 2015 - Accepted: March 24, 2015 - Distributed: May 31, 2016

(With 1 figure)

The family Mutillidae comprises a diverse group of solitary wasps, with over 4000 described species (Lelej, 2005). They are characterized by strong sexual dimorphism: all females are wingless, while males almost always are fully winged and capable of flight. Adult females are generally parasitoids of immature stages of other aculeate Hymenoptera. When inside a host nest they are known to drink hemolymph from the host larvae or prepupae. Adult males, on the other hand, generally feed on nectar. Additionally, both females and males can also collect honeydew from Hemiptera or sweet exudates from extrafloral nectaries as the main article in their diets (Brothers, 1989).

Extrafloral nectaries (EFNs) are nectar-producing plant structures that are usually not directly involved in pollination (Elias, 1983). Such structures are extremely variable anatomically and morphologically, and can be found on various above-ground plant parts, especially the leaf, petiole, pedicel and stem (Weber and Keeler, 2013). These EFNs are particularly attractive to ants (e.g. Almeida and Figueiredo, 2003), which play an important role in plant's indirect defense against herbivores (Koptur, 1992). They can also attract a variety of other nectar-foraging insects, like hymenopteran parasitoids that may attack herbivorous insects (Jervis et al., 1993).

According to Weber and Keeler (2013) EFNs are present in 3941 species of vascular plants, representing 745 genera in 108 families; yet as reported by the authors, only $1.0-1.8 \%$ of flowering plant species have EFNs. Here we present the first record of Mutillidae feeding on extrafloral nectaries in Malpighiaceae, a family of herbs, shrubs, vines and trees that comprises about 1300 species worldwide (Davis and Anderson, 2010).

In December 2013, during a field trip to the Serra da Canastra National Park, in Minas Gerais State, Brazil, we noticed the presence of a large number of hymenopterans flying near to/or feeding on EFNs of two different shrub species of Malpighiaceae, including winged males and wingless females of Mutillidae. The plants were identified as Banisteriopsis campestris (A.Juss.) Little, which bear a pair of EFNs at the base of the leaves (Figure 1B), and B. vernoniifolia (A.Juss.) B. Gates (Figure 1A), with the EFNs located at the leaf blades (Figure 1D). The observations were conducted on plants growing on red latosol soils in a grassland area near the "Curral de Pedras" (20.224 S $46.486^{\circ} \mathrm{W}$; 1400 m.a.s.1.).

Thirteen mutillid wasp specimens (ten males and three females) were collected feeding on EFNs of Banisteropsis. Following their collection, these specimens were identified as four different species, comprising subfamilies Mutillinae and Shaeropthalminae. Females were identified as Darditilla vianai Casal, 1968 (Figure 1E) and Pseudomethoca cfr. cerasina (Gerstaecker, 1874) (Sphaeropthalminae), and Timulla scoparia (Gerstaecker, 1874) (Mutillinae). Males were identified as Traumatomutilla floccosa (Gerstaecker, 1874) (five specimens), Pseudomethoca sp. (three specimens, probably the male of $P$. cfr. cerasina) (Sphaeropthalminae), and T. scoparia (two specimens) (Mutillinae) (Figure 1C). Eleven additional Hymenoptera families were collected feeding on EFNs of Banisteriopsis: Apidae, Bethylidae, Braconidae, Crabronidae, Eucharitidae, Eurytomidae, Evaniidae, Ichneumonidae, Pompilidae, Pteromalidae and Torymidae. The plants were also regularly visited by workers of two species of the ant genus Camponotus, C. novogranadensis Mayr, 1870 and Camponotus sp.

Information on the feeding habits of adult mutillid wasps seems to be scarce in the literature. To date there are only a few records of Mutillidae visiting EFNs: in Carlinville, IL, USA, Robertson (1929) reported the presence of males of Timulla vagans (Fabricius, 1798) and Sphaeropthalma sp. in EFNs of Chamaecrista fasciculata (Michx.) Greene (Fabaceae), and males of Ephuta scrupea (Say, 1836) and Sphaeropthalma sp. in EFNs of Strophostyles helvula (L.) Elliott (Fabaceae). In Brazil, Lenko (1970) recorded females of Traumatomutilla latevittata (Cresson, 1902) feeding on EFNs of a Mimosa sp. tree (Fabaceae), in Três Lagoas, Mato Grosso do Sul State. In the Pacific coast of Central America, Quintero and Cambra (2001) observed males of Dasymutilla araneoides (Smith, 1862) feeding on EFNs of Ipomoea pes-caprae (L.) R.Br. (Convolvulaceae) and Euphorbia hirta L. (Euphorbiaceae).

New records of feeding habits, like those presented here, are valuable because fewer than $4 \%$ of mutillid species have any biological traits studied (Brothers, 1989). 

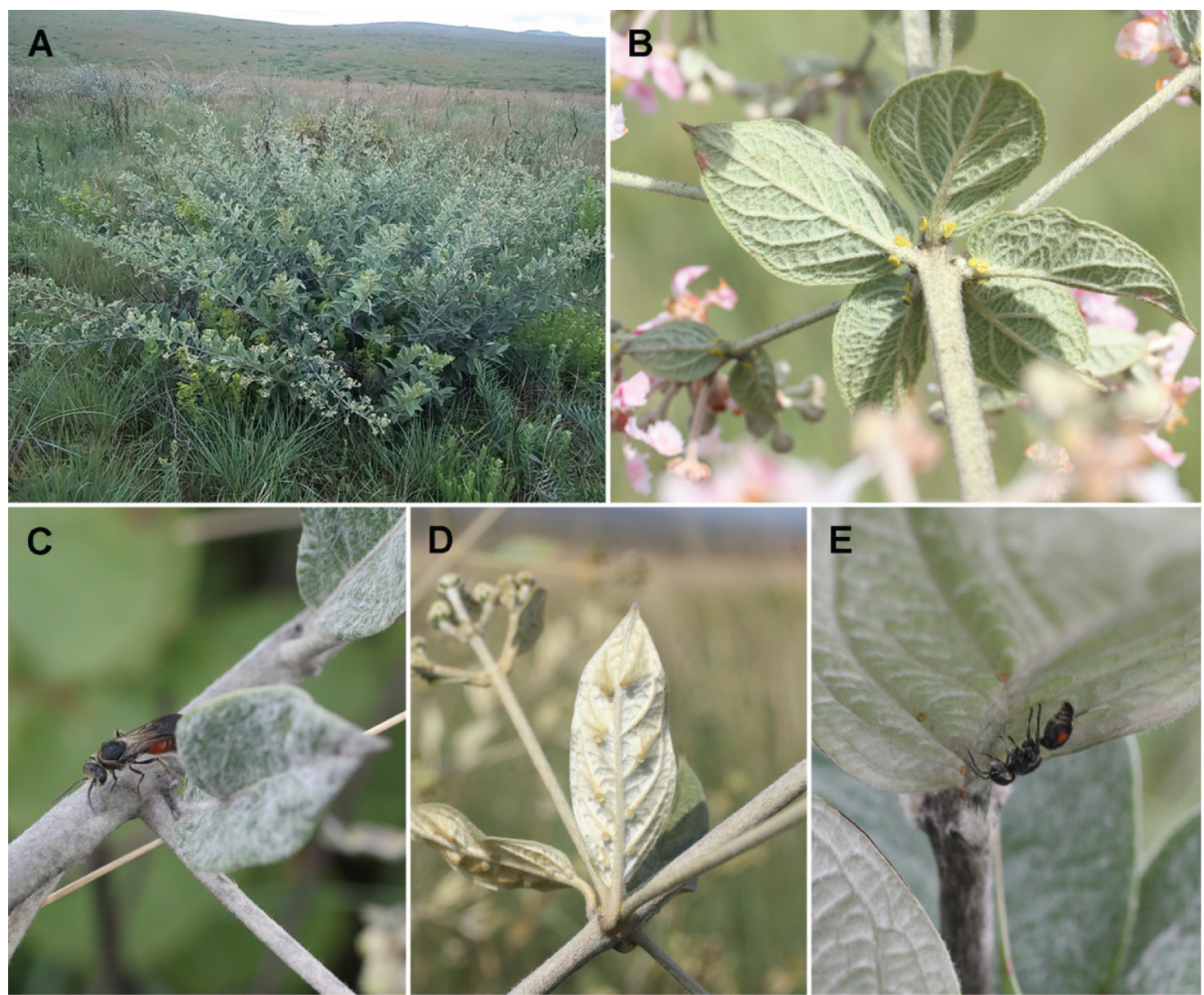

Figure 1. (A) An overview of the shrub Banisteriopsis vernoniifolia (A.Juss.) B. Gates; (B) EFNs of Banisteriopsis campestris (A.Juss.) Little, located at the base of the leaves; (C) Male of Timulla scoparia (Gerstaeker, 1874) visiting B. vernoniifolia; (D) EFNs located at the leaf blades of B. vernoniifolia; (E) Female of Darditilla vianai Casal, 1968 visiting B. vernoniifolia.

\section{Acknowledgements}

We would like to thank CNPq (Conselho Nacional de Desenvolvimento Científico e Tecnológico) for financial support: DRL (143491/2011-3), BBR (130397/2013-0), KAW (370106/2013-0), and GARM (304053/2012-0). All authors thank Dr. Maria Mamede (Instituto de Botânica, São Paulo) for plant species-level identifications and Dr. Rodrigo Feitosa (UFPR) for identification of the ants. ICMBio is thanked for granting the collecting permits (37953-2). This paper is part of the project "Complexos miméticos em vespas da família Mutillidae (Insecta, Hymenoptera): padrões de mimetismo e diversidade nos biomas brasileiros" (CNPq 402393/2012-0).

\section{References}

ALMEIDA, A.M. and FIGUEIREDO, R.A., 2003. Ants visit nectaries of Epidendrum denticulatum (Orchidaceae) in a Brazilian rainforest: effects on herbivory and pollination. Brazilian Journal of Biology $=$ Revista Brasileira de Biologia, vol. 63, no. 4, pp. 551-558. http://dx.doi.org/10.1590/S1519-69842003000400002. PMid:15029366.

BROTHERS, D.J., 1989. Alternative life-history styles of mutillid wasps (Insecta, Hymenoptera). In: M.N. BRUTON, ed. Alternative life-history styles of animals. Dordrecht: Kluwer Academic Publishers, pp. 279-291.

DAVIS, C.C. and ANDERSON, W.R., 2010. A complete generic phylogeny of Malpighiaceae inferred from nucleotide sequence data and morphology. American Journal of Botany, vol. 97, no. 12, pp. 2031-2048. http://dx.doi.org/10.3732/ajb.1000146. PMid:21616850.

ELIAS, T.S., 1983. Extrafloral nectaries: their structure and distribution. In: B.L. BENTLEY and T.S. ELIAS, eds. The biology of nectaries. New York: Columbia University Press, pp. 174-203.

JERVIS, M.A., KIDD, N.A.C., FITTON, M.G., HUDDLESTON, T. and DAWAH, H.A., 1993. Flower-visiting by hymenopteran parasitoids. Journal of Natural History, vol. 27, no. 1, pp. 67-105. http://dx.doi.org/10.1080/00222939300770051. 
KOPTUR, S., 1992. Extrafloral nectary-mediated interactions between insects and plants. In: E. BERNAYS, ed. Insect-plant interactions. Boca Raton: CRC Press, pp. 81-129.

LELEJ, A.S., 2005. Catalogue of the Mutillidae (Hymenoptera) of the Oriental Region. Vladivostok: Dalnauka. 252 p.

LENKO, K., 1970. A singular method of feeding of mutillid wasps. Entomological News, vol. 81, pp. 152.

QUINTERO, D. and CAMBRA, R.A., 2001. On the identity of Scaptopoda F. Lynch Arribálzaga, new taxonomic changes and new distribution records for Neotropical Mutillidae (Hymenoptera), with notes on their biology. Transactions of the American Entomological Society, vol. 127, pp. 291-304.

ROBERTSON, C., 1929. Flowers and Insects: lists of visitors to four hundred and fifty-three flowers. Lancaster: Science Press Printing Company. 221 p.

WEBER, M.G. and KEELER, K.H., 2013. The phylogenetic distribution of extrafloral nectaries in plants. Annals of Botany, vol. 111, no. 6, pp. 1251-1261. http://dx.doi.org/10.1093/aob/ mcs225. PMid:23087129. 